\title{
The $3 \times 3$ matrix as a tool for evaluation of technological position of the enterprise
}

\author{
Manuela Ingaldi $^{1, *}$, and Marina Zhuravskaya ${ }^{2}$ \\ ${ }^{1}$ Czestochowa University of Technology, Faculty of Management, Poland \\ ${ }^{2}$ The Ural State University of Railway Transport, Russia
}

\begin{abstract}
Technology is the way we do things. It is the application of knowledge to create products that serve human needs and aspirations. It decides about the success of the enterprises. The technological position of every enterprise can be treated as an element of its strategy. This position depends on existing technologies, equipment and on element deciding about its market position. For this evaluation a $3 \times 3$ matrix can be used. This matrix consists of 9 fields that correspond to the respective technological positions of the enterprise and help to identify its strategy in terms of technology. The research was shown on example the foundry. To evaluate its technological position it was necessary to indicate factors those that determine the technological possibilities of the company and those that determine its position on the market.
\end{abstract}

\section{Introduction}

The technology can be defined as a practical application of the knowledge in a specific method of producing goods or achieving a particular effect; that is the collection of techniques, skills, methods and processes used in the production of goods or services or in the accomplishment of objectives, such as scientific investigation. This definition suggests that, in order to produce products of the right quality level, which will find buyers on the market, the enterprise must have adequate knowledge of their production.

The word "technology" comes from the Greek words "techne" and "logos" (collection, reason). It means "a method of processing material goods into another useful good; also knowledge of this process" [1]. It is processing material goods in a useful goods in a targeted and cost-effective way," but also "technology" means "knowledge of the process.

Many products require the use or may be produced with different technologies. Their choice depends on many technical, economic, social or cultural factors, such as costs, time, legal restrictions, safety, comfort, etc. Thus, the technology and product quality, and at the same time the final result of production will be affected by production machines owned by the enterprise. All resources of enterprises are increasingly considered as potential strategic elements and the conditions of their development.

Very large impact on the effect of the technology therefore have a variety of resources. Many of these resources do not depend directly on the enterprise, but on its suppliers,

\footnotetext{
*Corresponding author: manuela@gazeta.pl
} 
and/or its environment. Lack of those resources often contributes to the loss of positions on the market. Therefore, actions for their development or their acquisition are such an important part of the strategic thinking of enterprise's management [2-4].

Competitiveness is the process by which one entity strives to outperform another. For an enterprise, being competitive implies that it has the ability to produce a product, in a timely and cost effective manner, which meets the test of the marketplace and the needs of customers [5]. The activities of enterprises are to gain and increase market share, which in turn determines their profits. And the profit is the main goal of every enterprise.

Technological strategy does not include only the selection of procedures and products, but the skills which are necessary to maintain the competitive advantage. It is not only about the ability how to produce or about knowledge of technology, but also about developing the skills of the sales, supply, financing, understanding the environment and involved processes and their consequences [6].

The research was shown on an example of a chosen enterprise. The purpose of this article is to evaluate the technological position of the enterprise from the foundry industry. For this purpose a little known and little-used $3 \times 3$ matrix was chosen. At the beginning those factors that determine the technological possibilities of the company and those that determine its position on the market were indicated. Then, based on their evaluations and averages of each group, the technological position in the $3 \times 3$ matrix was indicated.

\section{Literature review}

Many managers are aware of the strategic importance of technology in delivering value and competitive advantage of their enterprises and the industrial networks in which they operate $[7,8]$. This technology management framework includes some important elements such as technology management processes (identification, selection, acquisition, exploitation and protection), business processes (strategy, innovation and operations), highlighting the dialogue that is needed between the commercial and technological functions in the business to support effective technology management. It points to the link between the technological possibilities of the enterprise and its competitiveness, which in turn is used in a $3 \times 3$ matrix presented in the paper.

Scientists of the world have used the idea of a matrix to describe the various enterprise's scenarios, e.g. the technological one. Waters proposed to define the relationships between the customer and supplier based on a $2 \times 2$ matrix [9].

Zhuravskaya et al. have structured the problems solved in the logistics systems of different levels using the $3 \times 3$ matrix [10]. Khalil and Ezzat also [5] used the $3 \times 3$ matrix. This matrix is presented in Fig. 1. They used the matrix reflecting economic and technology momentum and competitive posture. Each of the entries in the matrix (dots) can be viewed as an option, deliberately chosen, to capitalize on. Furthermore, the clustering of the dots can be an indication of (and should reflect) the vision and general strategy of the organization. To exemplify, two clusters are shown. In this case the matrix can be used to compare position of one enterprise in comparison to position of other enterprises.

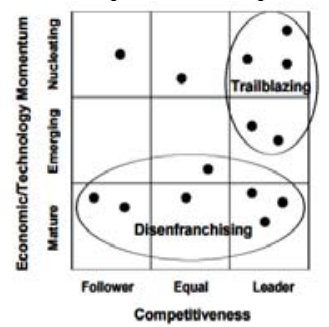

Fig 1. Profiling opportunities [5]. 
A bit different variant of the $3 \times 3$ matrix was proposed by Lowe [11]. The $3 \times 3$ matrix should be used to evaluate the strengths and weaknesses of the technology. Lowe called it as "the matrix of linkages between enterprise's market position and its technological possibilities". He also proposed the use of the matrix that would define the relationship of technological uncertainty and threats of the enterprise. Technology evaluation is often subjective, but with use of the $3 \times 3$ matrix this evaluation becomes more accurate. In this case, the matrix was used for a single enterprise. Thus, different elements deciding about position of the enterprise can be included. The basic version of the $3 \times 3$ matrix is shown in Fig. 2.

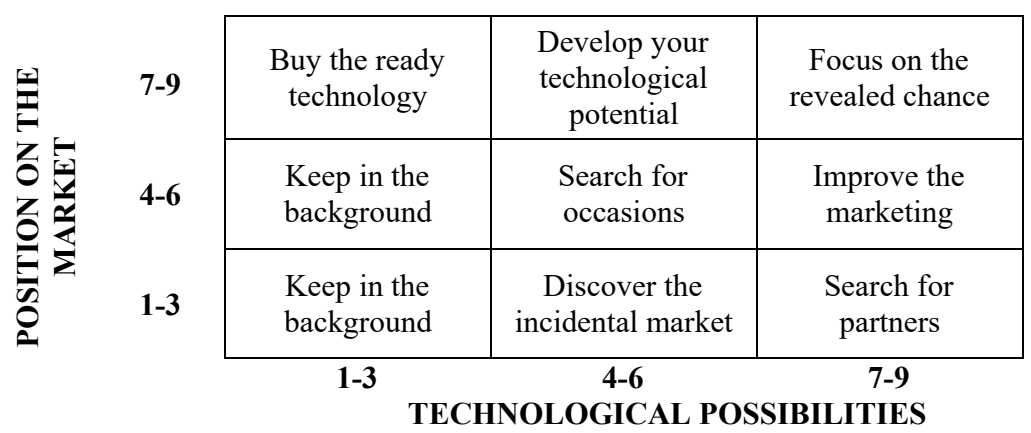

Fig 2. A scheme of the $3 \times 3$ matrix [11-13].

The $3 \times 3$ matrix consists of 9 fields that correspond to the respective technological positions of the enterprise and help to identify the way to proceed in terms of technology. It can therefore be used as a part of defining the strategy of the enterprise. The objective of any enterprise is the field marked as "Focus on the revealed chance".

The first changes to the basic version of the $3 \times 3$ matrix, presented in paper [12], are related to the axis. Its new version included the relation between the technological possibilities and competition of the product. This research was a part of the questionnaire which was filled by production workers of the enterprise, who often do not fully know the reality of enterprise. Respondents were asked for the evaluation both factors on a scale from 1 to 9 ( 1 - low, 9 - high evaluation). The matrix showed that the adopted scale of evaluation must be divided by 3 . It was necessary to change locations of the borderlines to avoid problem with interpretation of the results. After changes they were placed between the possible answers. In the $3 \times 3$ matrix the individual pairs of answers were marked. The field with the most pairs of responses was treated as the position of the enterprise.

Other suggestions, related to the matrix, were concerned with the research method [1314]. The first stage of the research was to determine the factors that would evaluate the technological position of the enterprise: these that determine the technological possibilities of the enterprise and these that determine its position on the market. All these factors were evaluated on a scale from 1 to 9 . However, due to the presence of negative factors that change the technological positions of the enterprise, it was decided to change the scale, where 1 indicates a negative impact, 5 is a neutral or very small impact, but there is a factor, while 9 indicates a positive impact. It was also assumed that the borderlines of individual fields have the half-values. Then, average values of both groups of factors were calculated. Those averages indicate the technological position of the enterprise. In case of this research the executives and managers took part. The procedure for the use of experts is more justified, since these are generally people associated directly with the research technology, they carry out the evaluation in many ways. 


\section{Metodology}

The research enterprise was founded in the 90. of the XX century, is located in the Lodzkie Voivodship. The main direction of its activities is the production of castings from Al-Si alloys, by the pressure method. The volume of production per year is estimated at approx. 2400 tons of castings. The product assortment reaches almost 400 different types of castings. The main customers of products are enterprises operating in following industries: automotive, electrical, household appliances, mechanical equipment, construction, for the gas industry, measurement and control equipment.

At the beginning, all the factors, which can have any influence on the research enterprise were listed and divided into two groups: determining the technological possibilities of the enterprise and determining its position on the market. The factors that did not fit into any of the groups have been omitted. All factors were evaluated on a scale presented in papers [13-14]. Finally, average of both groups were calculated and then, based on them, the position in the $3 \times 3$ matrix was indicated.

\section{Results}

Individual factors, determining position of the research enterprise on the market and its technological possibilities and their evaluations are presented in Table 1. The relations of both averages are presented in Fig. 4.

From Fig. 3 it results that the research enterprise is located in the field of the $3 \times 3$ matrix, which is marked as "improve the marketing". Factors determining the position of the enterprise on the market reached the average evaluation of 4.8, while its technological possibilities 7.3. Such position means that the research enterprise should put more emphasis on improving the factors related to its position on the market. Some factors had positive influence on results.

Table 1. List of factors for the $3 \times 3$ matrix [own study].

\begin{tabular}{|c|c|c|c|c|c|}
\hline \multicolumn{2}{|c|}{$\begin{array}{l}\text { Factors deciding about } \\
\text { technological possibilities }\end{array}$} & \multirow{2}{*}{$\begin{array}{c}\text { Evaluation } \\
8 \\
\end{array}$} & \multicolumn{2}{|c|}{$\begin{array}{l}\text { Factors deciding about } \\
\text { position on the market }\end{array}$} & \multirow{2}{*}{$\frac{\text { Evaluation }}{7}$} \\
\hline 1. & $\begin{array}{c}\text { Implemented } \\
\text { management systems }\end{array}$ & & 1. & Localization & \\
\hline 2. & Technical equipment & 6 & 2. & Position on the market & 5 \\
\hline 3. & Machine park & 5 & 3. & Regular customers & 7 \\
\hline 4. & Production technology & 7 & 4. & Competition & 2 \\
\hline 5. & Products quality & 8 & 5. & New markets & 5 \\
\hline 6. & $\begin{array}{c}\text { Operation of quality } \\
\text { department }\end{array}$ & 8 & 6. & Export & 6 \\
\hline 7. & Transport base & 6 & 7. & Marketing department & 2 \\
\hline 8. & $\begin{array}{l}\text { Assortments and its } \\
\text { possible extension }\end{array}$ & 8 & 8. & Advertising & 3 \\
\hline 9. & Production flexibility & 9 & 9. & $\begin{array}{l}\text { Demand and its possible } \\
\text { growth }\end{array}$ & 6 \\
\hline 10. & Experienced staff & 8 & \multirow{2}{*}{\multicolumn{2}{|c|}{ Average }} & \multirow{2}{*}{4.8} \\
\hline & Average & 7.3 & & & \\
\hline
\end{tabular}




\begin{tabular}{|c|c|c|c|c|}
\hline \multirow{3}{*}{ 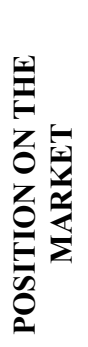 } & $7-9$ & $\begin{array}{l}\text { Buy the ready } \\
\text { technology }\end{array}$ & $\begin{array}{c}\text { Develop your } \\
\text { technological } \\
\text { potential }\end{array}$ & $\begin{array}{l}\text { Focus on the } \\
\text { revealed chance }\end{array}$ \\
\hline & $4-6$ & $\begin{array}{l}\text { Keep in the } \\
\text { background }\end{array}$ & $\begin{array}{l}\text { Search for } \\
\text { occasions }\end{array}$ & $\begin{array}{l}\text { Improve the } \\
\text { marketing }\end{array}$ \\
\hline & \multirow[t]{2}{*}{$1-3$} & $\begin{array}{l}\text { Keep in the } \\
\text { background }\end{array}$ & $\begin{array}{l}\text { Discover the } \\
\text { incidental market }\end{array}$ & $\begin{array}{l}\text { Search for } \\
\text { partners }\end{array}$ \\
\hline & & $1-3$ & 4-6 & $7-9$ \\
\hline
\end{tabular}

Fig 3. The $3 \times 3$ matrix for the research enterprise [own study].

Among the factors that determine the technological possibilities, the special attention should be given to production flexibility. Castings are often made on request, according to customer needs, therefore so high evaluation. 5 factors out of 8 received 8 , which means positive influence on the technological position: implemented management systems, products quality and operation of quality department, assortments and its possible extension, experienced staff. The assortments and its possible extension are connected with the production flexibility. If it comes to the operation of quality department, it has a partially positive effect on the products quality. Properly selected measuring machines, prepared control procedures and corrective actions allow for a well-conducted quality control. This can also indicate the main production problems and counteract them. The research enterprise has implemented an integrated management system, which has an impact on the process and the products quality. Employees of the research enterprise are people over 40, most well educated, but not necessarily in foundry, not always after studies.

It should be noted that among the factors that determine the technological possibilities, the machine park was evaluated as the lowest. The enterprise uses machines that have been bought in the late 90 . Those machines work without bigger breakdowns, but their efficiency is not as very high as it should be.

Among the factors that determine the position on the market, the special attention should be given to regular customers and localization. The research enterprise is located in the Lodzkie Voivodship, i.e. in the central Poland. This allows for easier access to potential customers from the country. The research enterprise has also signed long-term contracts with several customers, which allows the production also in times of lower demand.

In case of the factors determining the position of the enterprise on the market, several factors that negatively affected the position of the enterprise in the $3 \times 3$ matrix, were noted. Those are: the competition, marketing department and advertising. It should be kept in mind that in Poland there are many enterprises dealing with casting, hence such an evaluation. If it comes to marketing department and advertising, they are linked together. The research enterprise does not have the marketing department, its managers are dealing with it. It does not carry any advertising campaign, only a few posters with information and sometimes it advertised its products and services in professional journals.

It should be noted that many of the factors, that influenced the enterprise's position on the market, are external factors. So the enterprise cannot do anything to change them. Therefore, it should deal only with those factors, which were evaluated as quite high.

\section{Summary and conclusion}

In the paper, the $3 \times 3$ matrix, which includes elements associated with the technological possibilities of an enterprise and its position on the market, is presented. The technology 
used by individual enterprise determines the quality of the finished products, and thus the customer satisfaction. Its position on the market depends on the competitiveness of products. Therefore, it is important to determine an appropriate strategy, which will decide about further development of the enterprise.

In the paper, the results for the designation of technological position of the enterprise from foundry industry with regard to its strategy, were presented. For this purpose, the $3 \times 3$ matrix was used. It turned out that the research enterprise is located in the field of the matrix labelled as "improve the marketing". This means that the enterprise should put more emphasis on improving the factors related to its position on the market.

Among the factors that determine the technological possibilities of the enterprise the special attention should be given to production flexibility, implemented management systems, products' quality and operation of quality department, assortments and its possible extension, experienced staff, while among the factors that determine the position of the enterprise to the regular customers and localization.

In the article it was also shown that simple tool like the matrix of relations between position of the enterprise on the market and its technological possibilities, also known as $3 \times 3$ matrix, can easily be used by the enterprises to evaluate their operation and to determine the elements of their strategies. In addition, it was shown that easy tools, such as the $3 \times 3$ matrix, that are available in the literature and used by other scientists, can be subjected to small modifications, which allows for their better use.

\section{Reference}

1. K. Bialecki, A. Dorosz, W. Januszkiewicz, Stownik handlu zagranicznego (PWE, Warszawa, 1986)

2. E. Gwarda-Gruszczynska, Acta Univer. Lodz., Folia Oecon. 234, 265-275 (2010)

3. J.B. Barney, Gaining and Sustaining Competitive Advantage (Addison Wesley, New York-Paris, 1997)

4. P. Sygut, M. Krynke, Production Engineering Archives, 17, 32-35 (2017)

5. T.M. Khalil, H.A. Ezzat, Selected Discussion Papers presented at the Vienna Global Forum (Vienna, 2002)

6. J. Wisniewska, Studia I Prace W. N. E. i Z., 39 (1), 101-111 (2015)

7. R. Phaal, C.J.P. Farrukh, D.R. Probert, Techn. For. \& Soc. Ch., 71, 5-26 (2004)

8. D.R. Probert, R. Phaal, C.J.P. International Association for Management of Technology (IAMOT) Conference (Lausanne, 2000)

9. D. Waters, Logistics: An Introduction to Supply Chain Management (Palgrave Macmillan, New York, 2003)

10. M. Zhuravskaya, A. Lempert, E. Smorodintseva, Innotrans J. 5, 6, 20-23 (2012).

11. P. Lowe, The Management of Technology: Perception and Opportunities (Chapman and Hall, London, 1995)

12. S. Borkowski, R. Ulewicz, J. Selejdak, M. Konstanciak, D. Klimecka-Tatar, Proceedings of 21st International Conference on Metallurgy and Materials 1722-1728 (Brno, Czech Rep., 2012)

13. M. Ingaldi, Logistyka, 6, 12133-12136 (2014)

14. M. Ingaldi, Hutnik-Wiadomości Hutnicze, 81, 10, 714-717 (2012) 